\title{
The Starving Sex: Psychoanalysis of Gendered Identity Crisis in the Gothic Novel
}

\author{
Mujtaba Al-Hilo* \\ Lecturer at Imam Ja'afar Al-Sadiq University Iraq, Najaf \\ Email: Mujtaba.mohammedali@ sadiq.edu.iq

\section{Hayder Gebreen} \\ Lecturer at Imam Ja'afar Al-Sadiq University Iraq, Najaf
}

\author{
Article History \\ Received: November 21, 2020 \\ Revised: December 25, 2020 \\ Accepted: December 28, 2020 \\ Published: December 30, 2020
}

\begin{abstract}
This paper investigates the socio-historical context in which the Gothic novel appeared. It seeks to shed light on the psychological side of this debut. One of the problems of recent studies in this regard is that they tend to detach the appearance of the Gothic novel from the historical context that gave birth to this genre. This leads to inaccurate findings and conclusions because this genre rose out of necessity. It was a method of fighting back the suppressive social conditions from which females suffered. This study is necessary to reveal the oppressive context females endured, and how that patriarchal ideology was universally and rationally justified and eluded any possible questioning. This suppressive condition was deeply rooted in the unconscious of subjects. Gothic novel was a revolution against that prevailing ideology, socially, religiously, and intellectually. It was considered a form of atheism. In this regard, this paper seeks to question the validity of the appearance of this genre and the way it is justified. It also presents a host of findings that displays the necessity out of which this genre rose, with references to Emily Bronte's Wuthering Heights and Mathew Lewis' The Monk.
\end{abstract}

Keywords: Gothic novel; Ideology; Sexuation; Lacan; Freud; Zizek.

\section{Introduction}

After the emergence of the novel in the $18^{\text {th }}$ century, the Gothic novel snaked through the crowd of critiques that appealed to the novel, in general, to form a shock to major contemporary critics of the time. This newly created genre -the Gothic novel- strived to find a stable ground among the $18^{\text {th }}$-century readers, though confronted with tremendous oppositions from prominent figures, like Coleridge and Wordsworth (Gamer, 2002). This is ascribed to a state of rejecting any genuine form that disturbs the stability of the rising form of English literature. Romanticism in poetry prevailed the genre. Any competition was rejected. Nevertheless, Gothic literature, as a new rising genre challenged all obstacles to prove itself worth being a cornerstone in the literary realm.

It is an acknowledged condition that any literary genre, mode, or philosophy debut due to a socio-cultural demand. Literature is a process of mirroring the contextual needs of any specific era. According to Marxist critics, any attempt at writing is a pure reflection of the socio-psychological status of the author, a necessary aspect of writing which is a manifestation of the reality of the authors, a state known as "reflectionism" (Tyson, 1999). One cannot imagine a parentless literary work that belongs to no social conflict or political trauma. Otherwise, it would display no particular meaning, destined to be forgotten and faded away. This dogma of "reflectionism" is no exception in Gothic literature.

English literature yielded to the demands of cultural expectations of the time. Punter and Byron believe that the birth of the Gothic novel and its related factors were an attempt to challenge the soulless age of reason. "The reputation of the eighteenth century has mainly been as an age of reliance on reason", in which intellectual endeavors were not imagined out of the box of the limited rational thinking. They claim that it was "a time when enlightenment was seen as possible and the rational explanation of natural human activities formed an agenda in the service of which most of the European intellectuals of the age worked" (7). In this case, the rise of the Gothic novel formed a literary crisis that was not overcome only after long years of conflict, because it challenged the norm of the age of reason in a way that this debut resulted in a rupture and discontinuity of the expected literary tradition. It was as Foucault proposes that: "attention has been turned... away from vast unities like 'periods' or 'centuries' to the phenomena of rupture, of discontinuity" (4). In other words, the debut of the Gothic novel was a process of 'desedimnetation' of the literary norm of the age of reason. It implied the failure of the dominant intellectual ideology in a way that Gramsci describes the failure of political systems:

the ruling class has lost its consensus, i.e. it is no longer 'leading' but only dominant', exercising coercive force alone; this means precisely that the great masses have become detached from their traditional ideologies, and no longer believe what they used to believe (275-6). 


\section{Sumerianz Journal of Education, Linguistics and Literature}

Complete dependence on reason became futile after the masses lost their connection with any intellectual circle. Philosopher's big ideas were no longer 'leading', but only dominant in the academic halls. The Gothic novel led to a state of 'desedimentatoin' or crisis in the norm of the age. It introduced "the disruption of routinization" (Sayyid, 2015).

The appearance of the Gothic novel was not a reply to the luxurious demand of a socially privileged class. It is a genre of the oppressed gender that underwent the chains of social patriarchal traditions. It appeared naturally "for women to employ the Gothic tropes of predicament either directly... or implicitly in the less overtly political romance" as a strategy "to interrogate injustices against women" (Chaplin, 2011). The historical context of the time could not comprehend contemporary social concepts, like the 'freedom of speech'. Early feminists needed safer paths upon which they can tread without any direct accusation of revolting against the inherited heritage of masculinity.

Gothic novels dominated the literary scene by attempts of female writers as a reaction to the tyranny of the patriarchal society of the time. For example, Ann Radcliffe in her novels attempted to focus on the oppressive relationship of female characters with the society, and how they strived to establish a stable identity for themselves (Heiland, 2008). In other words, female characters feel a sense of identity loss and psychological weakness. These characters feel a sense of identity loss and psychological weakness. These characters are always squeezed by the threat of the society. These vulnerable characters always seek to gain access to a more established identity, mostly through marriage, to create a stable-self in the existence (Punter and Byron, 2004). In other words, a female character has no sense of existence. These female Gothic authors were trembling in loss of self. This is due to a long processed evolution of psychology theory by certain psychoanalysts.

The entire structure of the Gothic novel is a rejection of the patriarchal norm, starting from its genesis. This genre founded all its corners on the rejection of the norms of the rational patriarchal society, starting from its name. The name of 'Gothic' is borrowed from the north European tribes, called 'Visigoths' who defeated the mighty Roman Empire. Because the Romans were known with philosophy and reason, those tribes destroyed that political and intellectual order to replace it with savagery, irrationality, and illiteracy. (Chaplin, 2011). In this case, the best representation of the failure and defeat of the Age of Reason and its rationality is the invading tribes of Visigoths.

Punter and Byron propose a sharper comparison between the Gothic and the Age of Reason. Gothic seems to be a direct confrontation to the prior 'classical' age of the Seventeenth and Eighteenth centuries. Gothic Chaos, exaggeration, and convolution confronted the classical order, simplicity, purity, and limitation. "Gothic represented excess and exaggeration, the product of the wild and the uncivilized, a world that constantly tended to overflow cultural boundaries" (7).

The Gothic novel displayed its rejection of social norms even in its most minute details, as its settings. Before this genre's debut, women had no voice or social impact. The circle of their effect did not transgress their immediate families, because she was conceived as being unable to produce any rational or beneficial impact. The original sin, according to the Judeo-Christian theology, and the resulting miseries of Man suffices to put this irrational being under all possible chains not to destroy the second Garden of Eden men have built again. Her most sublime mission in life, however, was to raise her children to be righteous citizens in the future. In the Eighteenth and Nineteenth centuries, when the British Empire was at its climax, a moral woman was the one who could prepare her children to contribute to the building of the Empire abroad. "Thus woman's influence found itself becoming part of the myth of Britain's 'civilizing mission' abroad" (Morgan, 2007). In other words, a positive female citizen was the one that contributed to the development of the patriarchal Empire by subjectivizing her children with the imperial ideology. Otherwise, she would find herself lost, without any stable identity in the society.

As a compensation for this loss of identity and lack of social voice, she established her Gothic identity in voiceless settings, away from the heart of civilizations and crowded cities. Gothic settings are mostly situated in forgotten forests, misty air, nighttime, a place and time that are vague and less known: "the haunted, violent Gothic space - the castle, monastery or even the home - becomes the location of female struggle against various forms of patriarchal domination" (Chaplin, 2011). It was an inevitable result of a long journey of suppressive patriarchy that "included imprisonment, persecution, disinheritance and various forms of haunting" (207) that limited the social and cultural position of women.

\section{Methodology}

This paper depends on a host of theories by relevant thinkers. Because this study seeks to justify the appearance of Gothic fiction in its suppressive historical context, it depends on the theories of major psychoanalysts, mainly Sigmund Freud and Jacques Lacan. These two theorists present a realistic viewpoint towards the understanding of the context of the time. Furthermore, Otto Weininger is another thinker who displayed an accurate explanation of the mentality of females at that time. Louis Althusser is of significance here, because he justifies the functionality of certain ideologies. This study moves further to propose a more contemporary understanding of the historical context of the time by depending on the theories of Zizek (1994). It reads the ideological cause and effect of the Gothic fiction by, first, presenting the theories of these thinkers, and then, finding their manifestation in Emily Bronte's Wuthering Heights and Mathew Lewis' The Monk.

In Freud's Three Essays on the Theory of Sexuality, he believes that the distinct mark between the two sexes is the masculine or active principle and the feminine or passive principle sexually. Assuming that all libido, or sexual drive, is active, Freud then believes that it is a factor entirely related to masculinity (Thurschwell, 2009). In other words, females lack existence in sexual activity and must remain so, and any deviation from this norm is the destruction of social order. He proposes that males, in their early childhood, develop a sense of castration anxiety 


\section{Sumerianz Journal of Education, Linguistics and Literature}

while females are already born with this complex because they are deprived of a penis; when a woman observes this sexual positivity in the opposite sex, she believes that she has already been punished and castrated. Thus, she strives to fill this emptiness by a desire to get a child from her father, as a compensating strategy to fill her lack. In other words, a female is born with emptiness and a lack of real existence (58-9). However later, Freud confessed that because of female's voiceless social position, he failed to propose stable definitive theories of sexuality that concern women.

To a further extreme, Lacan proposed his theory that "Woman does not exist" (Homer, 2004). 'Woman', in fact, has no real signified: it is an empty signifier. Existence, for Lacan, is Symbolic, and since woman lacks the 'symbolic order', a process man undergoes, she does not really have the existence proposed by Lacan, because symbolic is phallic, and phallic is related to man. In this sense, "woman does not exist", and lacks a real self-identity, encircling her with epistemological complexes.

The other dimension of his a lack of existence in woman is that she lacks the needed discourse to express her existence. Language is attached and acquired during the symbolic order, a result of phallic: speech is phallic. As mentioned above, phallic is masculine. The 'other jouissance', as opposed to 'phallic jouissance' or masculine enjoyment, is also experienced by woman, but cannot be defined and spoken about (Homer, 2004). Thus, feminity lacks existence because she is unable to use a language of her own. This lack of existence may also transgress these Lacanian limits to become a more realistic manifestation.

\section{Discussion and Analysis}

\subsection{Creative Sanity of Madness}

Female madness is a recurrent theme in the Gothic novel. Madness is manifested in various forms of unnatural behavior, mostly uncanny. It is the ultimate form of rejection that Gothic writers could propose as an antidote to the irrational patriarchal society. It is a traumatic stage that denotes the failure of patriarchal rationality to provide an acceptable life without the inherited social chains. Madness is an implication of breaking the rules that the society had imposed upon its subjects. It is a strategy to emancipate herself from the prevailing patriarchal ideology that "emanate from social situations that render the female protagonist vulnerable, alienated and desperate" (213). This led to a crisis of psychoanalytical understanding in the succeeding thinkers, mostly Freud.

Zizek adds that "the 'enigma of woman' ultimately conceals the fact that there is nothing to conceal" (Zizek, 2001). Freud's failure to propose a proper sexual theory for women and prior social failures to comprehend the true nature of women led to an enigmatic status towards her. Vagueness leads to antagonism because of the unknown radiates peril. As a remedy to this enigmatic creature, she had to be silenced and muted. She represented identity violation and social disturbance, hiding behind the prevailing ideologies. The society situated her in a position of negativity and nothingness, but later she became a source of social power, as manifested in the Gothic novel. Zizek, in this sense, believes that: "this nothingness behind the mask is the very absolute negativity on account of which woman is the subject par excellent" in a way that is "not a limited object opposed to the force of subjectivity". This Hegelian analysis of Zizek proposes the ultimate social uprising against the dominant social ideologies. The negativity of the woman at the time rejected to absorb the norms of the time, erupted finally in the writings of Gothic authors in its mysterious silent and detached settings.

The failure of the patriarchal symbolic order to comprehend the true nature of women complicated the issues further. This misunderstanding increased the level of antagonism towards women because a man had to resort to his fantasy to compensate for this loss of knowledge about the other (woman). This repression leads to traumatic endings, like 'horror' in the Gothic novel. Zizek elaborates: "What we get in the place of this repression, what fills in its gap, is the multitude of "returns of the repressed", the series of "ordinary" signifiers" (originally italicized) (Parallax 38). The vague and voiceless identity must be filled. Since it was repressed for a long time, it returned in a form of trauma and identity violation. Moreover, this long time of repression naturally gives birth to a host of oppositional signifiers. In other words, Gothic novel denoted the formation of a new antagonistic ideology, that of feminism. Any ideology, including feminism, is formed through signifiers. Because feminism as an ideology of opposition to religion and social norms was not formally shaped, these signifiers remained floating in the background until the Gothic novel 'quilted' them. The process of quilting is a necessary stage for the formation of any specific ideology. "The 'quilting' performs the totalization though which this free-floating of an ideological element is halted, fixed" (Zizek, 2006). The Gothic novel represents the components of the rejection of the tradition and the rise of a new movement. It, in this sense, constituted the soul of feminism as an ideology of negativity, of atheism, and rejection of the prior norms. It violated the natural form of English literature. This justifies the ardent opposition of the Romanticism poets to this novel traumatic genre.

Otto Weininger theorizes about the social status of women in the eighteenth and nineteenth centuries. He believes that men are active, or subjects and women are passive, or objects, and thus, the women are driven by sexuality. A woman remains passive until she is brought into existence by a man's love. "Man's love, in other words, functions as a performative," Myers argues. He adds "Man projects onto woman an ideal she can never attain, and so, in loving woman, man really loves himself" (Myers, 2004). Man, through this process, creates an ideal image of himself when he loves a woman, he creates her and lets her remain in existence if a man embraces his sexuality at the expense of his spirituality. Thus, Lacan's claim that "woman does not exist" is justified here, for a woman is just an effect: she does not exist by herself (82). Weininger elaborates that "woman is inherently unfree, a slave to the phallus (or patriarchal law) who, if she attempts to repress this fact, will suffer from hysteria when her true nature fights back" (83). Though this might be perceived as an extremely misogynistic theory, it describes the suppressive status of a woman at the time. Gothic novels appeared in such a depressing context. 


\section{Sumerianz Journal of Education, Linguistics and Literature}

An example of a female Gothic character is Catherine Earnshaw, Emily Bronte's heroine in Wuthering Heights, who can be regarded as one of the best examples of a female's loss of identity. She felt the need of coming into existence socially and psychologically by gaining access to male's love, that of Heathcliff. She starves for that existence that she confesses: "He's more myself than I am. Whatever our souls are made of, his and mine are the same." She found her lost identity and existence in Heathcliff's love. Yet, when Edgar exposes his love to Catherine, she becomes overloaded with existence, leading her to deny her thirst for love unconsciously, after possessing more than one option, repressing her unfree mentality, according to Weininger, to result finally in hysteria and then death.

In this regard, early female Gothic writers attempted to gain a range of self-identity, to display themselves on the stage of life through displaying the oppression women had undergone, as opposed to male writers who penned their fiction in an authoritative style.

\subsection{Ideological Counterattack}

A systematic opposition to the patriarchal ideology of the time needed a counter ideology that quilts all the factors of the confrontation. Otherwise, the feminists' endeavors would be lost in the quicksand of oblivion. They needed an ideology, upon which, they can hover and depend, not to be lost and broken. Ideologies, in general, function as identity providers that unify their followers. Women's social revolution was labeled under the name of feminism. However, successful ideologies must function on the simplest social level to pave the way for the masses to engage and adopt this ideology. In other words, ideologies that remain dwelling in the realm of a theory are doomed to fail. They must find symbolization and a practical realm to be comprehended by the masses. Furthermore, this strategy sneaks into the very unconscious of its subjects to elude rational thinking. Human unconscious functions without obvious rational methodology. To Althusser, an ideology is "a set of structures that they impose on the vast majority of men, not via their "consciousness" (233). Feminism as an ideology found its way to the unconscious of its subjects to defy all the prior embraced patriarchal and religious ideologies through the Gothic novel.

Punter and Byron try to propose a comprehensive distinct line between male and female writers that "male Gothic tends to represent the male protagonist's attempt to penetrate some encompassing interior." They continue that on the other hand, "female Gothic more typically represents a female protagonist's attempts to escape from a confining interior" (Punter and Byron, 2004). In fact, they have failed to recognize the theories above that female's attempts to escape is, in reality, to escape from her genetic inborn psychological complexes, according to Freud and Lacan, trying to gain a stable self-definition of herself through writing and creating a fictional realm. On the other hand, in the quote above, the Gothic male's attempt to penetrate some encompassing interior is his endeavor to distort his spirituality and poses his love unto a female counterpart to give her the needed existence, as in Mathew Lewis' The Monk.

Mathew Lewis' masterpiece, The Monk, appeared to the public in 1796. This novel depended upon the small but effective heritage of the Gothic novels written previously, most importantly by Ann Radcliffe. Lewis' brilliance is also manifested in his ethical revolution to the patriarchal norms of his society. He was an atheist, who rejected the prevailing social traditions of misogyny, mainly inspired by the Catholic Church. The moral failure of the Church is intertwined within the plot and structure of the novel. Ambrosio, the monk, is engaged in a crime of rape and murder, supported by Satan himself. Lewis's dependence upon religion is not a matter of literary allegory for the sake of intellectual luxury. He seeks to propose the dominant Christianity as a gap that separates art from universality.

Christianity as the prevailing religion in the socio-historical context of The Monk functions as a gap that detaches the subjects from universality. Christianity subjectivized its ardent followers in a way that chained them from aspiring to the vaster circle of universal humanity. For Christianity to re-function properly after creating that gap between the content of universality and the meaning of humanity, it seeks to propose allegories to fill the created gap: "With religion, this immediate harmony is disturbed, there is a gap between the sensual content... and the true meaning, which is why organic unity is replaced by allegory" (Zizek, 2009). On the other hand, Lewis' allegorical engagement of the monk with the murder of Antonia is a clear representation of the social gap and disorder Christianity had imposed in the community.

Feminist atheism in the novel resides also in the inferior role of the Church in engaging with people's issues. The misogynist church, though the demeaning woman, embraces her only in case she becomes a source of fulfillment for its desires. When Matilda exposes her love for Ambrosia, she insists to stay at the abbey. When her request is declined, she raises the dagger, putting it on her chest, threatening to kill herself. The monk is seduced by the scene:

Oh! That was such a breast! The Moon-beams darting full upon it, enabled the Monk to observe its dazzling whiteness. His eye dwelt with insatiable avidity upon the beauteous Orb. A sensation till then unknown filled his heart with a mixture of anxiety and delight (65).

The church's unexpected greed, as apparent in the above text, was a fundamental reason that turned the intellectual arena against it.

Another refusal that the Gothic novel proposed in The Monk is that of a female as an object of social sacrifice. To find her position in the social ladder, in the Lacanian Symbolic Order, she had to be a representation of a sacrifice for the sake of others' comfort. Sacrifice comes as a gesture to the Other (Lacan's reference to God, Law, Superego, society, or any other prevailing power) that she lacks something: "one sacrifices not in order to get something from the Other, but in order to dupe the Other, in order to convince him/it that one is still missing something" (Zizek, 2001). A woman's sacrifice in the socio-historical context of the novel was a necessity to provide herself with proper identity. She would never become a subject in that ideological society without presenting herself as a domestic 


\section{Sumerianz Journal of Education, Linguistics and Literature}

sacrifice. However, the Gothic novel rejected this type of social absence. In The Monk, there is a smooth but fast transformation of the status of a woman. There is an exchange of positions between Ambrosio and Matilda:

But a few days had past, since she appeared the mildest and softest of her sex, devoted to his will, and looking up to him as a superior Being. Now she assumed a sort of courage and manliness in her manners and discourse but ill calculated to please him. She spoke no longer to insinuate, but command: He found himself unable to cope with her in argument, and was unwillingly obliged to confess the superiority of her judgement. Every moment convinced him of the astonishing powers

of her mind. (231)

Here, the woman is no longer a suppressive object of the superego, but a dominant subject of ego. She emancipated herself from Zizek's understanding of sacrifice: "Sacrifice is ultimately the gesture by means of which we aim at compensating the guilt imposed by the impossible superego injunction" (Zizek, 2001). She succeeded to overcome that everlasting social guilt that excluded her from the public sphere.

In The Monk, Ambrosio for long had been embracing Matilda, gifting her with existence and supporting her with the required self-identity, according to Weininger. Weininger believes that love is murderous since it dominates at the expense of spirituality, a necessary aspect of a male's survival. Love is, thus, a killing self-deceiving sense that ends tragically, as in the case of Ambrosio in the novel. After his love support, Matilda reveals herself to be a devil disguised in a woman's shape, a tragic consequence of love.

\section{Conclusion}

Hence, the Gothic novel succeeded to overcome the huge patriarchal heritage that confined a woman's existence with a host of limiting superego injunction, rejecting all the religious and social factors of the time. The Gothic novel is the ultimate manifestation of atheism that the social and religious structure had been fighting for centuries. Atheism, in this sense, is the refusal of all repressive ideologies that bind subjects to a set of irrational injunctions. According to the ideas discussed earlier, especially that of Freud and Lacan, this anti-tradition and undesired atheism is psychologically rooted in the unconscious of females due to the social position in which they are located. It is an imposition that chains females without acknowledgment.

\section{References}

Chaplin, S. (2011). Gothic Literature: Texts. Contexts, Connections.

Gamer, M. (2002). Gothic fictions and romantic writing in Britain. The cambridge companion to gothic fiction. Cambridge University Press: Cambridge.

Heiland, D. (2008). Gothic and gender: An introduction. John Wiley and Sons.

Homer, S. (2004). Jacques lacan. Routledge: New York.

Morgan, S. (2007). A victorian woman's place: Public culture in the nineteenth century. Tauris Academic Studies: London and New York.

Myers, T. (2004). Slavoj zizek. Routledge.: New York.

Punter, D. and Byron, G. (2004). The gothic. Blackwell Publishing: Oxford.

Sayyid, S. (2015). A fundamental fear: Eurocentrism and the emergence of Islamism. Zed Books Ltd. Islamism: London and New York.

Thurschwell, P. (2009). Sigmund freud. Routledge: New York.

Tyson, L. (1999). Critical theory today. Garland Pub: New York and London.

Zizek, S. (1994). The metastases of enjoyment: Six essays on woman and causality. Verso: London and New York.

Zizek, S. (2001). On Belief. Routledge: London and New York.

Zizek, S. (2006). The parallax view. The MIT Press: Cambridge and London.

Zizek, S. (2009). The monstrosity of christ: Paradox of dialectic? The MIT Press: Cambridge and London. 